\title{
Forthcoming Conferences
}

The annual conference of the Hegel Society of Great Britain, held in conjunction with the Hegel-Archiv at Bochum, will take place at Pembroke College, Oxford on 10th and Ilth September 1987 on the topic of Thought and Faith in the Philosophy of Hegel'. Inquiries should be addressed to Dr. John Walker, Department of German, University of Liverpool, 7/a Abercromby Square, P.O. Box 147, Liverpool L69 $3 \mathrm{BX}$. The full conference fee for overnight accommodation and meals will be $\mathfrak{f 3 6}$. All participants must in addition pay a registration fee of $£ 6$ ( $£ 3$ for graduate students).

The XXIst International Congress of Phenomenology is to be held from November 1st-5th 1987 in Belgrade. The theme of the congress is 'Historicity and Time in Hegel and Husserl' and is organized jointly by the Yugoslav Hegel Society and the World Institute for Advanced Phenomenological Research and Learning. The papers given at the congress will appear in a future volume of Analecta Husserliana.

The Hegel Society of America will hold its next meeting at Loyola University of Chicago on October $7,8,9,1988$. Papers are invited that deal with either particular problems of interpretation of the Science of Logic, or such broader issues as the nature of the Logic and its relationship to the rest of the System. Papers should not exceed 35 minutes reading time and should be submitted for consideration in this form. Each will be submitted to blind review by a programme committee. Four copies of the paper should be sent by January 30, 1988 to Professor George di Giovanni, Department of Philosophy, McGill University, 855 Sherbrooke Street West, Montreal, Quebec, H3A 2T7, Canada.

\section{New Arrangements for Purchasing The Owl of Minerva}

In an exchange agreement between the Hegel Society of America and the Hegel Society of Great Britain which is intended to help our readership avoid the costs involved in obtaining international money orders in foreign currency, any member of the Hegel Society of Great Britain wanting a one-year membership in the Hegel Society of America can join by sending $\mathbf{f 7 . 5 0}$ directly to the Secretary of the Hegel Society of Great Britain: Dr. Stephen Houlgate, Department of Philosophy, De Paul University, 2323 North Seminary Avenue, Chicago, Illinois 60614-3298, U.S.A.. Cheques should be made out to "The Hegel Society of Great Britain". Membership of the Hegel Society of America includes a subscription to The Owl of Minerva. 